\title{
HUBUNGAN PENGETAHUAN PERAWAT TENTANG KEJADIAN NYARIS CEDERA DENGAN SIKAP MELAPORKAN KEJADIAN NYARIS CEDERA
}

\author{
Elen Debora ${ }^{1}$, Wan Nishfa Dewi ${ }^{2}$, Yulia Irvani Dewi ${ }^{3}$ \\ ${ }^{1}$ Mahasiswa PSIK Universitas Riau, ${ }^{2,3}$ PSIK Universitas Riau \\ Program Studi Ilmu Keperawatan Universitas Riau Jalan Pattimura No 9 Gedung G Pekanbaru Riau \\ Kode Pos 28131 \\ Telepon: 085264767273 email: ellendebora4@gmail.com
}

\begin{abstract}
Abstrak
Patient safety adalah bebas dari insiden yang terjadi dengan tidak sengaja atau dapat dicegah sebagai hasil perawatan medis. Sikap perawat untuk melaporkan insiden keselamatan pasien termasuk Kejadian Nyaris Cedera (KNC) sangat dibutuhkan untuk mendukung program patient safety. Sikap dapat muncul dari pengetahuan akan patient safety. Penelitian ini bertujuan untuk mengetahui hubungan pengetahuan perawat tentang KNC dengan sikap melaporkan KNC. Penelitian ini merupakan penelitian deskriptif korelatif dengan pendekatan cross sectional. Sampel penelitian adalah perawat di ruang rawat inap sebanyak 89 responden menggunakan accidental sampling. Alat ukur yang digunakan adalah kuesioner yang terdiri dari 2 (dua) kuesioner untuk mengukur pengetahuan perawat tentang KNC dan sikap perawat melaporkan KNC. Analisis yang digunakan adalah analisis univariat dan bivariat dengan menggunakan Chi-Square. Hasil penelitian menunjukkan bahwa $p$ value 1,000 ( $p$ value $>0,05$ ) sehingga disimpulkan bahwa tidak ada hubungan antara pengetahuan perawat tentang KNC dengan sikap melaporkan KNC. Berdasarkan hasil penelitian diharapkan bagi perawat agar meningkatkan pengetahuan tentang KNC serta memberikan sikap yang positif untuk melaporkan KNC.
\end{abstract}

Kata kunci: KNC, patient safety, pengetahuan, sikap.

\begin{abstract}
Patient safety is free from incidents that occurred by mistake, or could have been prevented as a result of medical care. The attitude of nurses to report patient safety incidents including near miss is needed to support patient safety program. Attitudes may arise from the knowledge of patient safety. This study aims to determine the relationship between the knowledge of nurses about near miss with the attitude to report it. This research is a descriptive cross sectional correlative study. The samples were 89 nurses in the inpatient unit which selected using accidental sampling. Measuring instrument used was a questionnaire consisting of two questionnaire to investigate knowledge about near miss and the attitude of reporting near miss. Data analysis used were univariate and bivariate using Chi-Square. The results showed that the $p$ value 1,000 ( $p$ value > 0.05) so it was concluded that there was no correlation between the knowledge of nurses about near miss with the attitudes to report near miss. Based on the results of the study, it is expected to increase nurses' knowledge of near miss and to provide supporting and positive attitude to report near miss.
\end{abstract}

Keywords: attitude, knowledge, near miss, patient safety 
Elen Debora ${ }^{1}$, Wan Nishfa Dewi ${ }^{2}$, Yulia Irvani Dewi ${ }^{3}$ Hubungan Pengetahuan Perawat Tentang Kejadian Nyaris Cedera Dengan Sikap Melaporkan Kejadian Nyaris Cedera

\section{PENDAHULUAN}

Keselamatan (safety) telah menjadi isu global termasuk juga untuk rumah sakit. Ada lima aspek penting yang terkait dengan keselamatan (safety) di rumah sakit yaitu keselamatan pasien (patient safety), keselamatan pekerja atau petugas kesehatan, keselamatan bangunan dan peralatan di rumah sakit, keselamatan lingkungan dan keselamatan "bisnis" rumah sakit yang terkait dengan kelangsungan hidup rumah sakit. Keselamatan pasien merupakan prioritas utama untuk dilaksanakan dan hal tersebut terkait dengan isu mutu dan citra perumahsakitan (Depkes RI, 2008).

Kementerian Kesehatan RI menetapkan sistem akreditasi yang mengacu pada standar Joint Commission International (JCI) yang setelah diidentifikasi, diperoleh standar yang paling relevan terkait dengan mutu pelayanan rumah sakit yaitu Internasional Patient Safety Goals (sasaran internasional keselamatan pasien) rumah sakit. Keselamatan pasien menjadi indikator standar utama penilaian akreditasi (Dirjen Bina Upaya Kesehatan, 2012).

Keselamatan pasien (patient safety) rumah sakit merupakan suatu sistem dimana rumah sakit membuat asuhan pasien lebih aman yang meliputi pengkajian risiko, identifikasi dan pengelolaan hal yang berhubungan dengan risiko pasien, pelaporan dan analisis insiden (Depkes, 2008). Menurut Permenkes RI No 1691 tahun 2011, yang termasuk insiden keselamatan pasien adalah setiap kejadian yang tidak disengaja dan kondisi yang mengakibatkan atau berpotensi mengakibatkan cedera yang dapat dicegah pada pasien yang terdiri dari Kejadian Potensi Cedera (KPC), Kejadian Nyaris Cedera (KNC), Kejadian Tidak Diharapkan (KTD), Kejadian Tidak Cedera (KTC) dan Kejadian Sentinel.

Kejadian Nyaris Cedera (KNC) adalah suatu kesalahan akibat melaksanakan suatu tindakan (commission) atau tidak melakukan tindakan yang seharusnya diambil (omission) yang nyaris mencederai pasien karena belum sampai terpapar ke pasien (Permenkes Nomor 1691/Menkes/Per/VIII/2011). KNC lebih sering terjadi dibandingkan dengan jenis insiden keselamatan pasien lain, frekuensi terjadinya KNC 7-100 kali lebih sering terjadi. Sehingga seharusnya lebih banyak data KNC yang diperoleh dari laporan insiden keselamatan pasien (Mustikawati, 2011).

Laporan Institute of Medicine (2000) di Utah dan Colorado (USA) ditemukan 2,9\% dari kasus yang dilaporkan merupakan KNC dan 6,6\% nya meninggal dunia. Di Indonesia, laporan insiden keselamatan pasien dikategorikan masih langka untuk ditemukan karena standar pelayanan kesehatan yang mengutamakan keselamatan pasien di Indonesia masih kurang optimal (Depkes RI, 2008). Laporan insiden pada tahun 2007 menemukan dari 145 insiden yang dilaporkan 
tersebut didapatkan KNC sebanyak 69 kasus (47,6\%) (KKP-RS, 2008).

Standar keselamatan dilaksanakan melalui mekanisme pelaporan insiden, menganalisa, dan menetapkan pemecahan masalah. Pelaporan insiden ini bertujuan untuk menurunkan insiden dan mengoreksi sistem dalam rangka meningkatkan keselamatan pasien dan tidak untuk menyalahkan orang (non blaming) (Belinda, 2015). Pelaporan IKP memerlukan keterlibatan dan komitmen yang tinggi dari organisasi dan staf pemberi pelayanan termasuk perawat (Gunawan, 2015).

Hasil kajian yang membahas mengenai pelaporan insiden oleh perawat masih sangat terbatas dibuktikan oleh Karni (2009 dalam Yulia, 2010) di RS Tugu Ibu menjelaskan bahwa 80 perawat (58\%) memiliki budaya lapor insiden dalam kategori kurang baik dan 58 perawat (42\%) memiliki budaya lapor insiden dalam kategori baik.

Hasil wawancara dengan salah satu anggota tim keselamatan pasien rumah sakit (TKPRS) tempat dilakukan penelitian pada Oktober 2016, didapatkan bahwa sering ditemukannya kejadian yang dikategorikan termasuk dalam KNC di ruangan rawat inap. Perawat penemu KNC tidak melaporkan kepada atasan dan tim keselamatan pasien rumah sakit dengan alasan hal tersebut tidak mencederai pasien. Komite keselamatan rumah sakit sudah memberikan informasi terkait insiden keselamatan pasien kepada staf termasuk perawat terkait insiden keselamatan pasien, jenis insiden dan cara melaporkan insiden, namun secara spesifik terkait hal-hal apa saja yang termasuk KNC dan konsekuensi melaporkan belum diinformasikan secara detail dan menyeluruh kepada perawat, sehingga masih banyak ditemukan staf yang tidak mengerti tentang KNC.

Hasil wawancara peneliti dengan lima (5) orang perawat dari ruangan rawat inap yang berbeda didapatkan informasi bahwa dua (2) dari lima (5) orang perawat tidak mengetahui KNC. Tiga (3) dari lima (5) orang perawat yang mengetahui tentang $\mathrm{KNC}$ juga pernah mengalami kejadian yang dikategorikan termasuk dalam $\mathrm{KNC}$ di ruangan seperti menemukan kesalahan tanggal lahir pada pasien baru oleh petugas pendaftaran, diet pasien yang tidak sesuai dengan instruksi dokter penanggung jawab pasien dan kesalahan pada label obat yang tidak sesuai dengan obat dalam plastik obat. Perawat-perawat tersebut tidak melaporkan dengan alasan hal tersebut sudah langsung disadari sebelum ke pasien, takut disalahkan dan berpendapat kejadian itu terlalu merepotkan jika dilaporkan.

Oleh karena itu penelitian ini bertujuan untuk mengetahui hubungan pengetahuan perawat tentang kejadian nyaris cedera dengan sikap melaporkan kejadian nyaris cedera di salah satu rumah sakit di Kota Pekanbaru. 
Elen Debora ${ }^{1}$, Wan Nishfa Dewi ${ }^{2}$, Yulia Irvani Dewi ${ }^{3}$ Hubungan Pengetahuan Perawat Tentang Kejadian Nyaris Cedera Dengan Sikap Melaporkan Kejadian Nyaris Cedera

\section{METODE PENELITIAN}

Penelitian ini menggunakan desain penelitian deskriptif korelasi dengan pendekatan cross sectional. Studi korelasi ini merupakan penelitian hubungan antara dua variabel pada suatu situasi atau sekelompok subjek untuk melihat hubungan antara variabel satu dengan variabel lain. Untuk mengetahui korelasi antara suatu variabel dengan variabel lain tersebut diusahakan dengan mengidentifikasi variabel yang ada pada suatu objek kemudian diidentifikasi pula variabel yang ada pada objek yang sama dan dilihat apakah ada hubungan antara keduanya (Notoatmodjo, 2005).

Populasi dalam penelitian ini adalah perawat yang berdinas di ruangan rawat inap yaitu sebanyak 115 orang. Teknik sampling yang digunakan dalam penelitian ini adalah accidental sampling dengan kriteria inklusi yaitu perawat yang berdinas saat dilakukan penelitian. Jumlah sample sebanyak 89 orang. Alat pengumpul data adalah kuesioner yang disusun peneliti mengacu pada landasan teori dan telah melalui tahap uji validitas dan realibilitas.

Analisis data menggunakan analisis univariat dan analisis bivariat. Analisis univariat untuk melihat gambaran karakteristik responden. Mengidentifikasi pengetahuan perawat tentang kejadian nyaris cedera. Mengidentifikasi sikap perawat untuk melaporkan kejadian nyaris cedera. Analisis bivariat digunakan untuk melihat hubungan pengetahuan perawat tentang kejadian nyaris cedera dengan sikap melaporkan kejadian nyaris cedera dengan menggunakan uji Chisquare.

\section{HASIL PENELITIAN}

Hasil penelitian ini akan disajikan berdasarkan analisis yang digunakan.

\section{Analisis univariat}

Tabel 1

Distribusi karakteristik responden

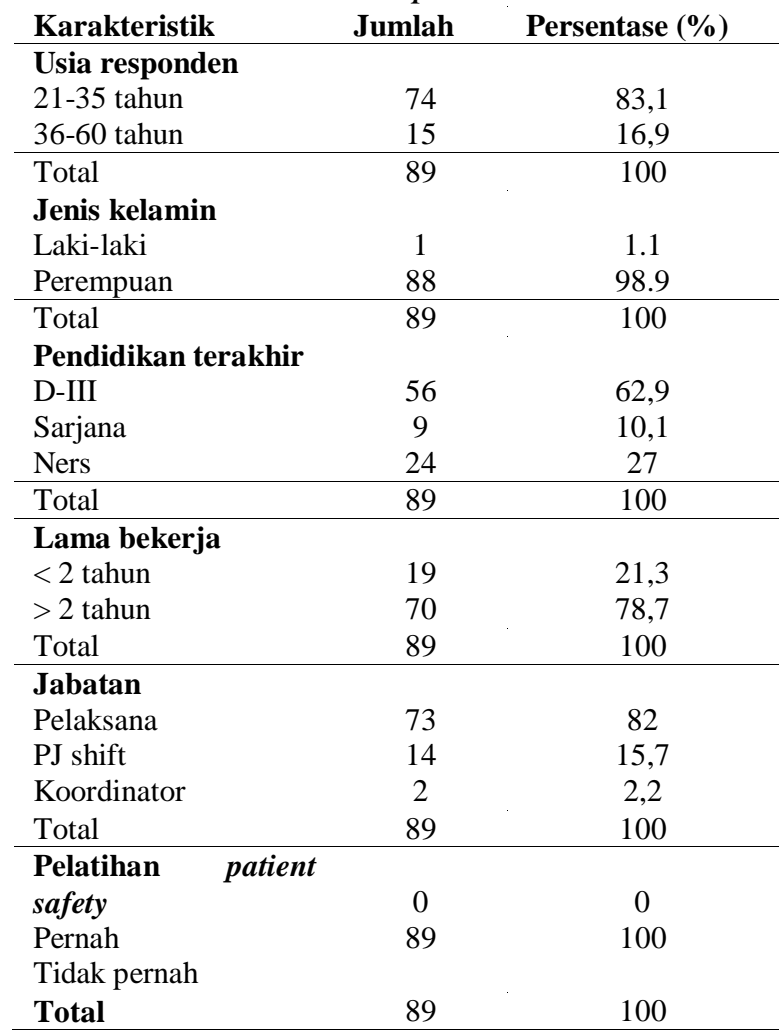

Dari tabel 1 diketahui bahwa mayoritas responden berada pada rentang umur 21-35 tahun yaitu 74 orang $(83,1 \%)$, hampir semua responden berjenis kelamin perempuan yaitu 88 orang $(98,9 \%)$, lebih dari setengah jumlah responden memiliki pendidikan treakhir D-III yaitu sebanyak 56 orang $(62,9 \%)$, mayoritas responden telah bekerja $>2$ tahun yaitu sebanyak 70 orang $(78,7 \%)$, responden 
terbanyak adalah perawat pelaksana yaitu 73 orang $(82 \%)$, seluruh responden tidak pernah mengikuti pelatihan patient safety yang bersertifikat (100\%).

Tabel 2

Distribusi frekuensi berdasarkan pengetahuan perawat tentang KNC

\begin{tabular}{lcc}
\hline Pengetahuan & Jumlah & Persentase (\%) \\
\hline Baik & 3 & 3,4 \\
Kurang baik & 86 & 96,6 \\
\hline Total & 89 & 100 \\
\hline
\end{tabular}

Gambaran responden berdasarkan pengetahuan tentang $\mathrm{KNC}$ adalah hampir seluruh responden memiliki pengetahuan kurang baik tentang KNC yaitu sebanyak 86 responden $(96,6 \%)$.

Tabel 3

Distribusi frekuensi responden berdasarkan sikap melaporkan KNC

\begin{tabular}{lll}
\hline Sikap & Jumlah & Persentase (\%) \\
\hline Positif & 32 & 36 \\
Negatif & 57 & 64 \\
\hline Total & 89 & 100 \\
\hline
\end{tabular}

Berdasarkan tabel 3 diketahui bahwa sikap melaporkan KNC cenderung negatif pada perawat yaitu sebanyak 57 orang (64\%).

\section{Analisis bivariat}

Untuk melihat hubungan antara variabel pengetahuan perawat tentang $\mathrm{KNC}$ dengan sikap melaporkan KNC dengan uji statistik Chi-square.
Tabel 4

Hubungan pengetahuan perawat tentang KNC dengan sikap melaporkan KNC

\begin{tabular}{|c|c|c|c|c|c|}
\hline \multirow{3}{*}{ Pengetahuan } & \multicolumn{2}{|c|}{ Sikap } & \multirow{2}{*}{ Total } & \multirow{2}{*}{$p$} & \multirow{2}{*}{$\begin{array}{l}\mathrm{O} \\
\mathrm{R}\end{array}$} \\
\hline & Positif & Negatif & & & \\
\hline & $\mathrm{N}$ & $\mathrm{n}$ & $\mathrm{n}$ & & \\
\hline Baik & $\begin{array}{c}1 \\
(33,3 \%)\end{array}$ & $\begin{array}{c}2 \\
(66,7 \%)\end{array}$ & $\begin{array}{c}3 \\
(100 \%)\end{array}$ & & \\
\hline $\begin{array}{c}\text { Kurang } \\
\text { baik }\end{array}$ & $\begin{array}{c}31 \\
(36 \%)\end{array}$ & $\begin{array}{c}55 \\
(64 \%)\end{array}$ & $\begin{array}{c}86 \\
(100 \%)\end{array}$ & 1.000 & .887 \\
\hline Jumlah & $\begin{array}{c}32 \\
(36 \%)\end{array}$ & $\begin{array}{c}57 \\
(64 \%)\end{array}$ & $\begin{array}{c}89 \\
(100 \%)\end{array}$ & & \\
\hline
\end{tabular}

Berdasarkan tabel di atas terlihat bahwa dari 3 responden yang memiliki pengetahuan baik tentang $\mathrm{KNC}$, hanya 1 responden $(33,3 \%)$ memiliki sikap positif melaporkan KNC dan 2 responden $(66,7 \%)$ memiliki sikap negatif melaporkan KNC. Sedangkan dari 86 responden yang memiliki pengetahuan kurang baik tentang $\mathrm{KNC}, 31$ responden (36\%) memiliki sikap positif dan 55 responden (64\%) memiliki sikap negatif.

Hasil uji statistik menunjukkan bahwa $\mathrm{p}$ value $=1,000>\alpha=0,05$ maka dapat disimpulkan bahwa tidak ada hubungan antara pengetahuan perawat tentang KNC dan sikap melaporkan KNC. Dari hasil analisis diperoleh nilai $\mathrm{OR}=0,887$, artinya perawat yang memiliki pengetahuan baik tentang $\mathrm{KNC}$ mempunyai peluang 0,887 kali untuk bersikap negatif melaporkan KNC dibanding perawat yang memiliki pengetahuan kurang baik.

\section{PEMBAHASAN}

Hasil penelitian terhadap 89 orang perawat didapatkan hasil bahwa mayoritas pengetahuan perawat tentang kejadian nyaris cedera kurang baik yaitu 86 orang $(96,6 \%)$. 
Elen Debora ${ }^{1}$, Wan Nishfa Dewi ${ }^{2}$, Yulia Irvani Dewi ${ }^{3}$ Hubungan Pengetahuan Perawat Tentang Kejadian Nyaris Cedera Dengan Sikap Melaporkan Kejadian Nyaris Cedera

Hasil penelitian menunjukkan dari 89 orang responden terdapat 74 orang yang berada pada usia dewasa awal (21-35 tahun). Usia dewasa awal termasuk dalam usia produktif dalam bekerja. Pengembangan kinerja pada usia produktif merupakan suatu fase dimana seseorang berusaha mengembangkan jati diri melalui pekerjaan atau aktifitas yang dilakukannya (Sudrajat, 2008). Nursalam (2008) menyatakan bahwa semakin cukup usia seseorang maka tingkat kematangan dan kekuatan akan lebih matang dalam kehidupan sehari-hari, tingkat kematangan dalam berfikir juga dipengaruhi oleh pengalaman. Umur seseorang dapat mempengaruhi pengetahuan, artinya semakin dewasa umur perawat maka kemungkinan semakin meningkat pengetahuan dan pengalaman yang dimilikinya.

Berdasarkan hasil penelitian diperoleh data mayoritas responden yaitu 88 responden $(98,9 \%)$ berjenis kelamin perempuan. Perawat yang mayoritas adalah perempuan berperan cukup banyak dalam pembangunan kesehatan karena dunia keperawatan bersifat mothernalistic, yang mencerminkan figur ibu atau seorang wanita (mother instict) dalam memberikan asuhan keperawatan, kasih sayang, dan bantuan (Priharjo, 2008).

Hasil penelitian menunjukkan responden terbanyak pada penelitian ini berada pada tingkat pendidikan Diploma Keperawatan 56 orang (62,9\%). Nursalam (2008) menjelaskan bahwa pendidikan D-III keperawatan menghasilkan perawat generalis sebagai perawat vokasional (ahli madya keperawatan), sebagai perawat vokasional diharapkan memiliki tingkah laku dan kemampuan profesional serta akuntabel dalam melaksanakan asuhan/praktik keperawatan dasar secara mandiri di bawah supervisi. Perawat D-III mempunyai kemampuan mengelola praktik keperawatan. Langkah awal yang perlu ditempuh oleh perawat profesional adalah mengembangkan pendidikan tinggi keperawatan dan memberikan kesempatan pada para perawat untuk melanjutkan pendidikan yang lebih tinggi. Manulang (dalam Rosyidah, 2008) dalam penelitiannya mengatakan bahwa keterampilan seseorang tergantung pada tingkat pendidikan, pengetahuan dan pengalaman seseorang.

Hasil penelitian menunjukkan responden terbanyak memiliki masa kerja antara $>2$ tahun yaitu sebanyak 70 orang $(78,7 \%)$. Mubarak dkk (2007 dalam Sumarni, Utami \& Elita, 2014), menyatakan lingkungan pekerjaan dapat menjadikan seseorang memperoleh pengalaman dan pengetahuan baik secara langsung maupun tidak langsung. Pengalaman merupakan suatu cara untuk memperoleh kebenaran pengetahuan, baik dari pengalaman sendiri maupun orang lain. Pengalaman sangat dibutuhkan dalam pendekatan dengan pasien dan menghindari risiko cedera. Robbins \& Judge (2008 dalam Yulia, 2010) mengatakan ada korelasi positif antara masa kerja perawat pelaksana dengan motivasi kerja perawat. 
Penelitian Ratnasih (2001, dalam Sudrajat 2008) mengemukakan bahwa masa kerja berdampak pada peningkatan kinerja, hal ini berarti semakin lama seseorang bekerja maka akan semakin meningkatkan keterampilan dan pengalaman dalam melaksanakan pekerjaan yang diembannya.

Hasil penelitian menunjukkan sebagian besar responden memegang jabatan sebagai perawat vokasional (perawat pelaksana) yaitu sebanyak 73 orang (82\%). KEPMENPAN (2001) menjelaskan tentang tugas jabatan perawat pelaksana beberapa diantaranya yaitu melaksanakan pengkajian keperawatan keluarga bukan lagi individu, melaksanakan tindakan keperawatan dasar kategori I-IV, melaksanakan tindakan keperawatan kompleks kategori I, melaksanakan pengelolaan pelayanan keperawatan di rumah sakit sebagai ketua tim perawatan, melaksanakan tugas jaga sore dan siaga di rumah sakit, melaksanakan tugas malam dan siaga di rumah sakit, melaksanakan tugas siaga "on call" di rumah sakit. Untuk memenuhi jabatan tersebut ada beberapa unsur yang mempengaruhi salah satunya yaitu pengetahuan dalam bentuk mengikuti pendidikan dan memperoleh gelar serta ijazah.

Hasil penelitian menunjukkan bahwa tidak ada responden yang pernah mengikuti pelatihan patient safety yang memiliki sertifikat. Nursalam dan Efendi (2008), menyatakan bahwa pelatihan merupakan poin penting untuk membentuk keperawatan profesional. Notoatmodjo (2007) mengatakan pelatihan memiliki tujuan penting untuk meningkatkan pengetahuan dan keterampilan sebagai kriteria keberhasilan program patient safety. Tujuan pelatihan merupakan upaya peningkatan sumber daya manusia termasuk sumber daya manusia tenaga kesehatan agar pengetahuan meningkat (Depkes, 2008).

Institute of Medicine (2000) dalam to Err Is Human: Building a safer health system menegaskan bahwa peran program edukasi dalam mengenalkan keselamatan pasien (patient safety) dapat meningkatkan identifikasi terhadap terjadinya kesalahan dan mencegah terjadinya kesalahan itu sendiri. Penelitian Murdyastuti (2010) tentang pengaruh persepsi pengetahuan tentang patient safety terhadap pelaksanaan program patient safety memaparkan adanya pengaruh persepsi pengetahuan tentang patient safety terhadap pelaksanaan program patient safety.

Hasil uji statistik untuk variabel pengetahuan perawat tentang kejadian nyaris cedera dari 89 responden bahwa hampir seluruh responden memiliki tingkat pengetahuan kurang baik tentang KNC yaitu sebanyak 86 responden $(96,6 \%)$. Hasil kajian terhadap jawaban responden tentang pengertian patient safety dan KNC sudah dijawab mayoritas responden dengan benar tetapi mayoritas responden belum mengetahui hal-hal terkait waktu pelaporan KNC dan kejadian-kejadian yang termasuk KNC. 
Elen Debora ${ }^{1}$, Wan Nishfa Dewi ${ }^{2}$, Yulia Irvani Dewi ${ }^{3}$ Hubungan Pengetahuan Perawat Tentang Kejadian Nyaris Cedera Dengan Sikap Melaporkan Kejadian Nyaris Cedera

Pengetahuan merupakan hasil dari tahu yang terjadi setelah orang melakukan penginderaan terhadap suatu objek tertentu dan diperoleh dari pendidikan formal dan informal. Pengetahuan atau kognitif memegang peranan penting dalam terbentuknya tindakan seseorang karena ternyata tindakan yang didasari pengetahuan akan lebih langgeng daripada tindakan yang tidak didasari pengetahuan (Notoatmodjo, 2012). Pengetahuan atau kognitif merupakan domain yang sangat penting untuk terbentuknya tindakan seseorang (overt behavior) (Effendy, Ferry, \& Makhfudli, 2009).

Hasil penelitian menunjukkan bahwa responden memiliki sikap yang negatif untuk melaporkan KNC yaitu sebanyak 57 orang dari 89 responden (64\%). Sesuai dengan teori yang dikatakan oleh Gunarsa \& Gunarsa (2008) sikap akan terus terbentuk dan mempengaruhi nilai hidup seseorang. Sikap kadang-kadang sulit diubah dan baru akan berubah bila telah ada pemahaman akan pengertian mengenai sebab terbentuknya sikap tersebut.

Sikap terbentuk karena adanya interaksi individu dengan lingkungannya atau disebut juga karena adanya perpaduan faktor internal dan faktor eksternal. Faktor internal seperti keadaan fisiologis, emosi, motif, minat dan aspek psikologis lainnya. Faktor eksternal seperti pengalaman, norma atau nilai dan pendidikan. Pengaruh sosial merupakan sumber pembentukan sikap yang paling penting yaitu orang tua, teman sebaya dan media massa (Saam \& Wahyuni, 2013)

Hasil kajian terhadap jawaban responden terkait sikap melaporkan KNC adalah responden cenderung melaporkan KNC karena terlanjur diketahui oleh orang lain. Teori tindakan beralasan menyatakan bahwa tindakan melaporkan tidak hanya dipengaruhi oleh sikap saja namun dipengaruhi juga oleh norma subyektif yang ada yaitu apa yang orang lain kehendaki untuk individu perbuat (Azwar, 2013). Artinya sikap individu saja tidak cukup untuk membuat individu untuk berperilaku melaporkan atau tidak melaporkan adanya KNC tetapi harus didukung oleh norma subyektif yaitu keinginan mayoritas orang atau pihak-pihak yang memiliki pengaruh besar di lingkungan yang juga menghendaki individu untuk melaporkan jika terjadi KNC.

Hasil analisis hubungan pengetahuan perawat tentang $\mathrm{KNC}$ dengan sikap melaporkan KNC didapatkan bahwa dari 3 responden yang memiliki pengetahuan baik tentang $\mathrm{KNC} 2$ orang $(66,7 \%)$ cenderung memilki sikap yang negatif untuk melaporkan KNC. Uji statistik diperoleh $p$ value $=1,000>$ $\alpha=0,05$ yang berarti Ho gagal ditolak, sehingga dapat disimpulkan tidak terdapat hubungan yang signifikan antara pengetahuan perawat tentang KNC dengan sikap melaporkan KNC.

Hasil penelitian ini berbanding terbalik dengan penelitian yang dilakukan oleh Anggraeni (2016) yang menyatakan bahwa penentuan sikap yang didasari oleh 
pengetahuan dan kesadaran akan lebih kuat sehingga sikap lebih tertanam di dalam kepribadian. Penelitian yang dilakukan oleh Bantu, Mulyadi dan Bidjuni (2014) yang mengatakan adanya hubungan pengetahuan perawat dengan penerapan identify patient correctly yaitu dari 48 orang perawat terdapat 23 orang yang memiliki pengetahuan baik dan menerapkan identify patient correctly juga berbanding terbalik dengan hasil penelitian ini.

Notoatmodjo (2012) mengatakan sikap yang utuh terdiri dari tiga (3) komponen yaitu kepercayaan atau ide dan konsep terhadap suatu objek, kehidupan emosional atau cara mengevaluasi suatu objek dan kecenderungan untuk bertindak (tend to behave). Notoatmodjo (2012) juga mengatakan selain pengetahuan, pikiran, keyakinan dan emosi juga memegang peran penting dalam pembentukan sikap yang utuh. Pengetahuan akan membawa seseorang untuk berpikir dan berusaha tetapi dalam berpikir komponen emosi dan keyakinan ikut bekerja dalam menentukan sikap.

Hasil penelitian juga menunjukkan dari 86 responden yang memiliki pengetahuan kurang sebanyak 55 responden (64\%) menunjukkan sikap negatif, hal ini dikarenakan perawat belum pernah mengikuti pelatihan mengenai patient safety yang bersertifikat sehingga pengetahuan belum memadai. Sosialisasi oleh TKPRS Eka Hospital tentang patient safety sudah sering dilakukan namun spesifik terkait KNC belum disosialisasikan secara menyeluruh oleh tim KPRS.

\section{SIMPULAN}

Dari hasil penelitian ini dapat disimpulkan bahwa pengetahuan baik terkait kejadian nyaris cedera memiliki sikap negatif melaporkan kejadian nyaris cedera yaitu 66,67\%. Dari uji statistik didapatkan tidak adanya hubungan yang signifikan antara pengetahuan perawat tentang $\mathrm{KNC}$ dengan sikap melaporkan KNC ( $p$ value $=1,000$ )

\section{SARAN}

1. Bagi perkembangan ilmu keperawatan

Bidang ilmu keperawatan khususnya manajemen keperawatan hendaknya senantiasa mengembangkan keilmuannya terkait dengan konsep-konsep patient safety. Penelitian ini dapat menambah pembelajaran dan materi mengenai patient safety serta dapat digunakan untuk mengembangkan wawasan mahasiswa keperawatan dalam bidang manajemen keperawatan.

2. Bagi rumah sakit

Rumah sakit hendaknya lebih memberikan pelatihan dan sosilaisasi tentang patient safety kepada perawat untuk meningkatkan pengetahuan perawat tentang patient safety termasuk kejadian nyaris cedera.

3. Bagi perawat

Perawat-perawat khususnya yang bekerja di rumah sakit agar lebih meningkatkan pengetahuan terkait patient 
Elen Debora ${ }^{1}$, Wan Nishfa Dewi ${ }^{2}$, Yulia Irvani Dewi ${ }^{3}$ Hubungan Pengetahuan Perawat Tentang Kejadian Nyaris Cedera Dengan Sikap Melaporkan Kejadian Nyaris Cedera

safety dan kejadian nyaris cedera serta mendukung program-program rumah sakit terkait patient safety termasuk pelaporan insiden keselamatan pasien untuk meningkatkan keamanan bagi pasien rumah sakit.

4. Bagi penelitian selanjutnya

Bagi peneliti selanjutnya, hasil penelitian ini dapat dijadikan sebagai data dan informasi untuk mengembangkan penelitian lebih lanjut terkait faktor-faktor yang mempengaruhi sikap perawat untuk melaporkan insiden keselamatan pasien.

\section{DAFTAR PUSTAKA}

Anggraeni, D. (2016). Pengaruh budaya keselamatan pasien terhadap sikap melaporkan insiden pada perawat di instalasi rawat inap rumah sakit tk. $\mathrm{dr}$. Soepraoen. Jurnal aplikasi manajemen vol. 14 no. 2. Diperoleh tanggal 29 Januari 2017 dari http://jurnaljam.ub.ac.id

Azwar, S. (2013). Sikap manusia teori dan pengukurannya. Yogyakarta: Pustaka Pelajar.

Bantu, A., Mulyadi, \& Bidjuni, H. (2014). Hubungan pengetahuan perawat dengan penerapan identify patient correctly di RSUP Rata Totok Buyat Kabupaten Minahasa Tenggara. Diakses dari http://ejournal.unsrat.ac.id tanggal 29 Januari 2017

Belinda, M. (2015). Pelaporan insiden keselamatan pasien. Diperoleh tanggal 20 September $2016 \quad$ dari http://ppds.fk.ub.ac.id/wpcontent/uploads/ 2015/10/2015_ Pelaporan-Insiden.pdf

Depkes RI. (2008). Panduan nasional keselamatan pasien rumah sakit Edisi ke II. Jakarta.

Direktorat Jenderal Bina Upaya Kesehatan. (2012). Standar akreditasi rumah sakit. Jakarta.
Effendy, Ferry, \& Makhfudli. (2009). Keperawatan kesehatan komunitas. Jakarta: Salemba Medika.

Gunarsa, S \& Gunarsa, SD. (2008). Psikologi Perawatan. Jakarta: Gunung Mulia diperoleh tanggal 27 Desember 2017 dari https://books.google.co.id

Gunawan, Fajar, Y. W., \& Tatong, H. (2015). Analisis rendahnya pelaporan insiden keselamatan pasien di Rumah Sakit. Jurnal Kedokteran Brawijaya, Vol. 28, Suplemen No. 2. Diperoleh tanggal 10 September 2016 dari http://jkb.ub.ac.id

Institute of Medicine (US). (2000). Committee on quality of health care in America. Washington (DC): National Academies Press (US). Diperoleh tanggal 10 Oktober 2016 dari https://www.ncbi.nlm.nih.gov/pubmed/25 077248

KEPMENPAN. (2001). Jabatan fungsional perawat dan angka kreditnya. Jakarta.

Komite Keselamatan Pasien Rumah Sakit. (2008). Pedoman pelaporan insiden keselamatan pasien. Jakarta.

Murdyastuti, S. (2010). Pengaruh persepsi tentang profesionalitas, pengetahuan patient safety dan motivasi perawat terhadap pelaksanaan program patient safety di ruang rawat inap RSO Prof. DR. $R$. Soeharso Surakarta. Tesis. Universitas Sebelas Maret, Surakarta. Diperoleh tanggal 12 November 2016 dari http://www.eprints.uns.ac.id

Mustikawati, H. Y. (2011). Analisis determinan kejadian nyaris cedera dan kejadian tidak diharapkan di unit perawatan rumah sakit pondok indah Jakarta. Tesis. Universitas Indonesia, Depok.

Notoatmodjo, S. (2012). Promosi kesehatan dan perilaku kesehatan. Jakarta: Rineka Cipta.

Notoatmodjo, S. (2007). Kesehatan masyarakat ilmu dan seni. Jakarta: Rineka Cipta.

Notoatmodjo, S. (2005). Metodologi penelitian kesehatan. Jakarta: Rineka Cipta.

Nursalam. (2008). Manajemen keperawatan aplikasi dalam praktik keperawatan profesional. Jakarta: Salemba Medika. 
Permenkes RI No. 1691/MENKES/PER/VIII/2011.

Keselamatan pasien rumah sakit. Jakarta.

Potter, P.A., \& Perry, A.G. (2005). Buku ajar fundamental keperawatan: konsep, proses, dan praktik. Edisi 4. Volume 1. Alih Bahasa: Yasmin Asih, dkk. Jakarta: EGC.

Priharjo, R. (2008). Konsep dan perspektif praktik keperawatan. Jakarta: EGC.

Rosyidah, Haryono, Oktafiani, R. (2008). Hubungan karakteristik perawat dengan kinerja perawat dalam menangani ODHA di RS PKU Muhammadiyah Yogyakarta. Diperoleh tanggal 23 Januari 2017 dari Jurnal Kesehatan Masyarakat: 181-19.

Saam, Z. S. \& Wahyuni, S. (2013). Psikologi Keperawatan. Jakarta: Raja Grafindo Persada.

Sudrajat, D. A. (2008). Hubungan antara analisis karakteristik dengan pemenuhan hak-hak pasien. Fakultas Ilmu Keperawatan Universitas Indonesia. Diperoleh dari http://lib.ui.ac.id tanggal 23 Januari 2017

Sumarni, E.E.S, Utami, G.T., Elita, V. (2014). Hubungan tingkat pengetahuan dan sikap perawat tentang pemberian obat terhadap tindakan pendokumentasian keperawatan. Diperoleh tanggal 21 Januari 2017 dari Jurnal Online Mahasiswa Program Studi Ilmu Keperawatan Vol 1, No. 1

Yulia, S. (2010). Pengaruh pelatihan keselamatan pasien terhadap pemahaman perawat pelaksana mengenai penerapan keselamatan pasien di rumah sakit tugu ibu Depok. Tesis. Universitas Indonesia, Depok. Diperoleh tanggal 12 November 2016 dari http://lib.ui.ac.id/file?file=digital/137266T\%20Sri\%20Yulia.pdf 